\title{
Energy saving analysis of industrial structure in Hebei province
}

\author{
Zhang Yan ${ }^{1, a^{*}}$, Liu Xin ${ }^{2, b}$ \\ ${ }^{1}$ Associate Professor, Hebei University of Science and Technology, Shijiazhuang Yuhua District, \\ 26th Street Yuxiang, China. \\ ${ }^{2}$ Hebei University of Science and Technology, Shijiazhuang Yuhua District, 26th Street Yuxiang, \\ China. \\ a32218605@qq.com, b794389191@qq.com
}

Keywords: structural adjustment; energy consumption; energy intensity.

\begin{abstract}
Total control of energy consumption and energy structure optimization, the process of China's economic development has become a major task in the current. For it is in Hebei Province, in order to account for the dominant position, the need to comprehensively promote the restructuring and upgrading, to break the bottleneck of resources and environmental constraints, accelerate economic growth trends in the environment of Beijing, Tianjin and collaborative development. This paper analyzes the relationship between the structural adjustment of the industrial sector and energy consumption as well as for the energy intensity of the impact, according to the method of scenario analysis, the results can save energy by adjusting the industrial structure of the industry.
\end{abstract}

\section{Introduction}

Iron, steel, cement and glass are four major pillars of Hebei's economy. These industries' inherent dependence on energy resources, determines Hebei's lower economic value and heavy structure, meanwhile, determines Hebei's another identity----the province of energy consumption, resource consumption and pollution emissions. Hebei has heavy industrial structure, the industry of raw materials and industries of high consumption of energy and heavy pollution are relatively concentrated, energy consumption structure is unreasonable. For example, in 2013, the coal consumption accounted for $88.67 \%$ of total energy consumption, higher than the national average of $22 \%$. Therefore, only promoting industrial transformation and upgrading can break the "neck bottles" constrained by resource environment.

\section{The relation between structure adjustment and energy consumption}

By calculation, in Hebei province, from 2005 to 2011, the ratio of the primary industry, construction industry and the tertiary industry has been less than the unit added value of energy consumption intensity of the entire industry, while the industry energy consumption intensity has been higher the unit added value of energy consumption intensity of the entire industry (see table 1). Therefore, Hebei's economic structure has a space for optimization, it can reduce the total energy consumption and improve energy utilization by adjusting the economic structure in Hebei province. Here is the direction for adjusting the economic structure in Hebei province: improve the status of the primary industry, construction industry and the tertiary industry in Hebei province, on the contrary, lower the ratio of industry. 
Table 1 compares the average energy consumption of each industry in Hebei energy intensity and strength of the entire industry [tce / $10^{4}$ yuan ]

\begin{tabular}{|c|c|c|c|c|c|}
\hline \multirow[b]{2}{*}{ year } & \multicolumn{4}{|c|}{ energy intensity } & \multirow{2}{*}{$\begin{array}{l}\text { The } \\
\text { average } \\
\text { energy } \\
\text { intensity }\end{array}$} \\
\hline & $\begin{array}{l}\text { Primary } \\
\text { Industry }\end{array}$ & Industry & $\begin{array}{l}\text { Building } \\
\text { industry }\end{array}$ & $\begin{array}{l}\text { Tertiary } \\
\text { Industry }\end{array}$ & \\
\hline 2005 & 0.380 & 3.37 & 0.358 & 0.413 & 1.130 \\
\hline 2006 & 0.383 & 2.943 & 0.353 & 0.393 & 1.018 \\
\hline 2007 & 0.323 & 2.697 & 0.338 & 0.362 & 0.930 \\
\hline 2008 & 0.301 & 2.305 & 0.302 & 0.332 & 0.810 \\
\hline 2009 & 0.292 & 2.358 & 0.271 & 0.303 & 0.806 \\
\hline 2010 & 0.268 & 2.165 & 0.278 & 0.287 & 0.749 \\
\hline 2011 & 0.242 & 2.012 & 0.284 & 0.263 & 0.700 \\
\hline 2012 & 0.222 & 1.925 & 0.266 & 0.254 & 0.667 \\
\hline 2013 & 0.185 & 1.890 & 0.262 & 0.258 & 0.649 \\
\hline
\end{tabular}

Data source: " Economic Yearbook of Hebei " over the years

In this paper, industrial structure is divided into two parts, that is, the internal industry of industry and the internal industry of the tertiary industry. The internal industry of industry are the 39 industries noted as double-digit industry code in the "Categorization of National Economy Industries" (GB/4754-2011); the internal industry of the tertiary industry is divided into three industries according to the statistics of "China's energy statistics yearbook 2010", that is, transportation, warehousing and postal service; wholesales and retails; accommodations, catering, financial sector, real estate industry and other industries. Thereof, the impact of 39 industries of the internal industry of industry on industry energy-saving structure is so complicated. In addition, because the data is not easily acquired, and in order to facilitate the analysis, the statistics of this paper is consistent with the one in "Hebei Economic Yearbook," the internal 39 industries of industry are classified according to the industrial energy consumption intensity and economy development characteristics. It is divided into 3 parts as 6 high energy consumption industries, 5 machinery and equipment manufacturing industries and other industries.

Table 2 Industry Energy Consumption Intensity in Hebei [tce $/ 10^{4}$ yuan]

\begin{tabular}{c|c|c|c}
\hline \multirow{2}{*}{ Year } & \multicolumn{3}{|c}{ Energy Consumption Intensity } \\
\cline { 2 - 4 } & $\begin{array}{c}\text { 6 high energy } \\
\text { consumption } \\
\text { industries }\end{array}$ & $\begin{array}{c}5 \text { machinery and } \\
\text { equipment } \\
\text { manufacturing } \\
\text { industries }\end{array}$ & other industries \\
\hline 2005 & 1.993 & 0.222 & 0.330 \\
\hline 2006 & 1.870 & 0.178 & 0.330 \\
\hline 2007 & 1.586 & 0.152 & 0.280 \\
\hline 2008 & 1.449 & 0.143 & 0.350 \\
\hline 2009 & 1.157 & 0.095 & 0.198 \\
\hline 2010 & 0.982 & 0.085 & 0.146 \\
\hline 2011 & 0.864 & 0.079 & 0.112 \\
\hline 2012 & 0.836 & 0.055 & 0.105 \\
\hline 2013 & 0.839 & 0.048 & 0.094 \\
\hline
\end{tabular}

Data source: "Hebei Economy Yearbook" over the years

The ratio changes of various industries has different influences on unit GDP energy consumption intensity. If the ratio of the 6 high energy industries could be reduced, it could lower the unit GDP energy consumption intensity, on the contrary, if the ratio of the 5 machinery and equipment manufacturing industries could upgrade, it could lower the unit GDP energy consumption intensity. 


\section{The impact of structure adjustment on energy consumption intensity}

By adjusting the economic structure of Hebei province to lower Hebei's energy consumption level is the prerequisite of assumptions, which is the impact on unit GDP energy consumption intensity caused by the proportion changes of industries. Please see the following assumptions.

Assumption 1: the proportion change of industries in Hebei Province will influence the unit GDP energy consumption intensity in this region.

Assumption 2: the proportion change of profession in Hebei Province will influence the unit GDP energy consumption intensity in this region.

\section{change. \\ Scenario analysis of energy consumption intensity influenced by Industry proportion}

In this paper, according to the computing method for industry proportion change to unit GDP energy consumption intensity written in Qi Ye's "China Low Carbon Development Report (2011-2012)", taking scenario 1 of table 3 as an example, formula 1 is the concrete computing formula.

$\mathrm{A}_{\mathrm{GDP}}=\left\{\left[\mathrm{e}_{5}+\mathrm{e}_{1} \times\left(\mathrm{p}_{1}-1 \%\right)+\mathrm{e}_{2} \times\left(\mathrm{p}_{2}+1 \%\right)+\mathrm{e}_{3} \times \mathrm{p}_{3}+\mathrm{e}_{3} \times \mathrm{p}_{3}\right] \div \mathrm{e}_{\mathrm{GDP}}-1\right\} \times 100$.

1: Primary Industry2: Industry3:Building 4:Tertiary Industry5:Life（the same below）

In this formula, $A_{G D P}$ is the added rate of the unit GDP energy consumption intensity (\%); e refers to the energy consumption intensity (tce / $10^{4}$ yuan); p is the proportion of industry, dimensionless. In addition, the energy consumption intensity of virtual residential sectors=residential sector energy consumption / regional GDP

Using the relevant data and combining with Equation 1 in Hebei Province to analyze the impact of energy consumption intensity caused by industry proportion changes from the year 2005 to 2013, we can get the result in table 3 .

Table 3 the impact of unit GDP energy consumption intensity caused by industry proportion changes

\begin{tabular}{c|l|c}
\hline & \multicolumn{1}{|c|}{ industrial structure change scenarios } & $\begin{array}{l}\text { Changes in energy intensity per unit } \\
\text { of GDP }\end{array}$ \\
\hline scenario 1 & $\begin{array}{l}\text { the first industry decreased by 1\%, industrial } \\
\text { rose 1\% }\end{array}$ & $1.47 \%$ \\
\hline scenario 2 & $\begin{array}{l}\text { the first industry decreased by 1\%, the tertiary } \\
\text { industry increased by 1\% }\end{array}$ & $0.22 \%$ \\
\hline scenario 3 & $\begin{array}{l}\text { industry fell 1\%, the tertiary industry } \\
\text { increased by 1\% }\end{array}$ & $-1.138 \%$ \\
\hline actual & $\begin{array}{l}\text { Primary industry rose 0.38 percent, 1.06 } \\
\text { percent decline in the industrial, construction } \\
\text { fell 0.07\%, the tertiary industry rose 0.15\% }\end{array}$ & $-5.6 \%$ \\
\hline
\end{tabular}

Note: The above scenarios are the result of the arithmetic value from 2005 to 2013, the actual value is the one of 2013 compared with 2012.

According to the calculation results we can see, different industrial proportion changes have different impacts on unit GDP energy consumption intensity. Unit GDP energy consumption intensity will be increased when the industrial proportion of high energy consumption industries increased, on the contrary, it will be decreased when the proportion decreased. For the tertiary industry, increasing the proportion of its industry, if it is to squeeze the proportion of primary industry, the energy consumption intensity per unit of GDP will be increased, if it is to squeeze the proportion of industry, will make the unit of GDP energy intensity reduce. Thus, in order to achieve the purpose of reducing energy intensity per unit of GDP, the proportion of industry should be reduced and the proportion of tertiary industry should be improved.

Then assumption 1 has been proven.

The actual situation of 2013 Hebei is as follows: compared with the energy saving effect of industrial structure, the primary industry rose 0.38 percent, 1.06 percent decline of industrial, construction fell $0.07 \%$, the tertiary industry rose 0.15 percent and ultimately lead to energy intensity 
per unit of GDP decreased by 5.6\%. Obviously, it should continue to reduce the proportion of industry, increase the proportion of tertiary industry to achieve higher energy levels.

\section{Scenario analysis of energy consumption intensity influenced by Industry proportion} change.

By adjusting the proportion changes of six high energy-consuming industries, five mechanical equipment manufacturing and other industries in these three areas to analyze the unit GDP energy consumption intensity influenced by industrial proportion change. Taking scenario 1 of table 4 as an example, Equation 2 and Equation 3 are main computing formulas.

$\mathrm{A}_{2}=\left\{\left[\mathrm{e}_{\mathrm{a}} \times\left(\mathrm{p}_{\mathrm{a}}-1 \%\right)+\mathrm{e}_{\mathrm{b}} \times\left(\mathrm{p}_{\mathrm{b}}+1 \%\right)+\mathrm{e}_{\mathrm{c}} \times \mathrm{p}_{\mathrm{c}}\right] \div \mathrm{e}_{\mathrm{GDP}, 2005} \times 100\right\}$.

$\mathrm{A}_{\mathrm{GDP}}=\{[\mathrm{e} 5+\mathrm{e} 1 \times \mathrm{p} 1+\mathrm{e} 2 \times(1+\mathrm{A} 2 / 100) \times \mathrm{p} 2+\mathrm{e} 3 \times \mathrm{p} 2+\mathrm{e} 4 \times \mathrm{p} 4] \div \mathrm{eGDP}-1\} \times 100$.

a: six high-energy b: 5 machinery and equipment manufacturing c: Other 28 projects

In Equation 2 and 3, $\mathrm{A}_{\text {industrial }}$ and $\mathrm{A}_{\mathrm{GDP}}$ respectively refer to the unit industrial added value and the unit GDP energy consumption intensity added rate(\%); e refers to energy consumption intensity, tce / million; p is the proportion of the industry,\%; e is the GDP energy consumption intensity of virtual life, tce / million.

Relevant data are substituted into Equation 2 and Equation 3, the calculated results are shown in Table 4. Combined with the results of Scenario 1 and Scenario 2 can be learned: For low energy intensity of 5 machinery and equipment manufacturing, increased its share to reduce energy intensity per unit of GDP, the proportion declined of the six energy-intensive industries will reduced the unit GDP energy consumption intensity.

Then assumption 2 has been proven.

The actual situation of Hebei in 2013: the proportion of the six energy-consuming industries fell 2.74 percent, five mechanical equipment manufacturing sector rose 1.07 percent, 1.67 percent increase in the proportion of other industries. According to the formula 2 and 3, in 2013, the proportion of actual changes in industry caused Hebei energy intensity per unit of GDP fell by 2.41 percent (see Table 2).

$\mathrm{A}_{\mathrm{GDP}}=\left\{\Sigma\left[\left(\mathrm{p}_{\mathrm{m}, 2012}-\mathrm{p}_{\mathrm{m}}, 2005\right) \times\left(\mathrm{e}_{2}-\mathrm{e}_{\mathrm{m}, 2005}\right)\right] \times\left(\mathrm{G}_{2,2005} \div \mathrm{GDP}_{2005}\right)\right\} \div \mathrm{e}_{\mathrm{GDP}, 2005} \times 100$.

Note: $\mathrm{m}=1$ ton $_{\mathrm{m}}$

In the above formula, $\mathrm{n}_{\mathrm{m}}=1 、 2 、 3$, (1: six energy-intensive industries,2: Five machinery and equipment manufacturing,3: other industries);m stands for the three internal industries divided in this paper; e industry representatives industrial energy consumption intensity, tce / ten thousand yuan; G industry representatives Industrial added value, yuan; other symbols are the same as before.

Table 4 the impact of the internal industry structure changes on unit GDP energy consumption intensity

\begin{tabular}{l|l|c}
\hline & industrial structural changes within the industry scenario & $\begin{array}{l}\text { Changes in energy } \\
\text { intensity per unit of } \\
\text { GDP }\end{array}$ \\
\hline scenario 1 & industrial structural changes within the industry scenario & $-0.7187 \%$ \\
\hline scenario 2 & $\begin{array}{l}5 \text { machinery and equipment manufacturing industry } \\
\text { increased by 1\%, the other 28 industries decreased by } \\
1 \%\end{array}$ & $-0.7175 \%$ \\
\hline scenario 3 & $\begin{array}{l}\text { The proportion of the six energy-consuming industries } \\
\text { fell 2.74 percent, five mechanical equipment } \\
\text { manufacturing sector rose 1.07 percent, 1.67 percent } \\
\text { increase in the proportion of other industries }\end{array}$ & $-2.41 \%$ \\
\hline
\end{tabular}

Note: The above scenarios are the result of the arithmetic value from 2005 to 2013, the actual value is the one of 2013 compared with 2012. 


\section{Strengthen industrial policy, adjust industrial structure}

Based on the correlation analysis of the industrial structure in Hebei above, the province needs to establish long-term mechanism of low-carbon policy and promote the development of low-carbon economy. On one hand, making rational planning of overall layout, determining the long-term strategy and target of industry development in Hebei province, clearly pointing out the main industry functional position, industry layout, main industry cluster and industry develop direction in different area of Hebei province, leading industry upgrading and perfecting Industrial Development Guide Catalog and admittance criterion of key industries in Hebei province. On the other hand, speeding up the adjustment of industrial structure and taking a new road to industrialization. At present, the proportion of China's secondary industry accounted for the largest, its output growth mainly depends on energy and capital investment, so biggest carbon emissions. Hebei, as a traditional industrial province, the proportion of the total industrial output value is higher than the national average, the industrial production mainly depends on high investment and high emissions of heavy chemical industry. On the other hand, the development of the tertiary industry is very slow. In order to achieve a low carbon economy development mode, Hebei needs to speed up the development of the tertiary industry, optimize the internal structure of the second industry, make the technological progress as the first driving force and upgrade new and high technology industries, speed up the transformation of the traditional heavy industry.

\section{References}

[1] Zhang Yan, Chen Wei. Low Carbon Economy and Regional Industrial Structure Adjustment [C]. Intellectual Property Press .2014.6

[2] Xiong Huawen analysis based on energy consumption per unit GDP energy saving potential and empirical research [J]. "China Energy", 2011 (4).

Study [2] Han Zhiyong, Wei Yiming, Fan Ying. Chinese energy intensity and economic structure variation [J]. "Mathematical Statistics and Management", 2004 (1).

[3] T., Zhang Xiliang. China's industrial structure change on the impact of rising energy intensity of GDP and trend analysis [J]. "Environmental Protection", 2005 (12).

[4] Li Li, Wang Feng. China manufacturing energy intensity factor Decomposition [J]. "Quantitative and Technical Economics Research", 2008 (10).

[5] Qi Ye. China Low Carbon Development Report. Social Sciences Documentation Publishing House .2011.11 (66-96) 